\title{
Childhood obesity: prevention is better than cure
}

This article was published in the following Dove Press journal:

Diabetes, Metabolic Syndrome and Obesity:Targets and Therapy

15 March 2016

Number of times this article has been viewed

\section{Aakash Pandita' \\ Deepak Sharma ${ }^{2}$ \\ Dharti Pandita ${ }^{3}$ \\ Smita Pawar ${ }^{4}$ \\ Mir Tariq \\ Avinash Kaul ${ }^{6}$}

'Department of Pediatrics, SMGS Hospital Jammu, Jammu and Kashmir, India; ${ }^{2}$ Department of Pediatrics, $\mathrm{Pt}$ Bhagwat Dayal Sharma Post Graduate Institute of Medical Sciences, Rohtak, Haryana, India; ${ }^{3}$ Department of Microbiology Jammu University, Jammu, Jammu and Kashmir, India; ${ }^{4}$ Department of OBG Fernandez Hospital, Hyderabad, Telangana, India; ${ }^{5}$ Department of Orthopedics, Kokilaben Dhirubhai Ambani Hospital, Mumbai, India; ${ }^{6}$ Department of Surgery, Acharya Shri Chander College of Medical Sciences and Hospital, Jammu, Jammu and Kashmir, India
Correspondence: Aakash Pandita Department of Pediatrics, SMGS Hospital, 55A Indira Nagar B.B, Jammu, Jammu and Kashmir, Srinagar, 190004 India Email aakash.pandita@gmail.com

\begin{abstract}
Obesity and its associated comorbidities have emerged as a major health problem garnering interests from both public health agencies and mainstream media consumers. With increasing awareness on its impact on health, finances, and community at large, it has come to the forefront for scientific research and development of health plans. The need for better strategies and novel interventions to manage obesity is now being recognized by the entire health care system. Obesity and overweight is now the fifth leading global risk factor for mortality. Strategic investment is thus urgently needed to implement population-based childhood obesity prevention programmes which are effective and also culturally appropriate. Population-based prevention is crucial to stem this rising tide of childhood obesity which is fast reaching epidemic proportions. Obesity has its onset very early in life; therefore, children constitute a major group of this disease. It is thus imperative to lay utmost importance on prevention of obesity in children and herald its progress, if present already. Furthermore, treatment is still in preliminary stage, so early prevention holds better than treatment at later stages. This article is an attempt to lay emphasis on childhood obesity as a problem that needs to be recognized early and measures for its prevention.
\end{abstract}

Keywords: overweight, obesity, prevention, assessment, body mass index, nutrition assessment, treatment

\section{Introduction Obesity and its assessment}

The mechanisms involved in weight regulation and the development of obesity in children are varied and include genetic, environmental, and developmental factors. The relative importance of each of these mechanisms varies substantially between individuals and populations and is a subject of ongoing research. ${ }^{1}$ IOTF (International Obesity Task Force) defines overweight and obesity in children 2-18 years of age using body mass index (BMI) cutoff points of 25 and $30 \mathrm{~kg} / \mathrm{m}^{2}$, respectively. ${ }^{2}$ As the child's BMI varies with age, different age-specific cutoffs have been used to define overweight and obesity. Children are thus defined as being overweight or obese if they have a BMI above the cutoff for the given age and sex. ${ }^{3,4}$ Accurate height and weight measurements are an integral part of general physical examination. Its role in early recognition of excessive weight gain makes it an important component of any visit to a primary health care center. ${ }^{5} \mathrm{BMI}$ is now recommended as the single best indicator of overweight and obesity in children and adolescents in clinical practice. ${ }^{6-8}$ submit your manuscript | www.dovepress.com Dovepress http://dx.doi.org/10.2147/DMSO.S90783 


\section{Why should we care about childhood obesity?}

There are two main reasons to target childhood obesity. First, overweight and obese children and teens are much more likely to become obese as adults compared to normal BMI children, and second, it is more challenging for these adults to lose the excess weight once they become obese. Newer drugs and bariatric procedures for treating obesity-related health problems have emerged but these procedures are costly and have their own complications. Thus, prevention of childhood obesity with emphasis on increased physical activity is of prime importance. ${ }^{9-11}$

The modern society and culture has managed to oust routine physical activity out of everyday life for most children and made energy dense, low nutrient food and beverages more affordable and accessible, making them far more appealing than their healthier counterparts. Behavioral changes and lifestyle modifications are the primary tools for reducing obesity. However, if the environment contributes to the unhealthy eating practices and sedentary lifestyle, strategies and interventions relying solely on individual "self-control" will not be very effective. Children are less equipped to make informed choices about what is healthy and what is not, making it all the more important to concentrate on modifying the environment. This will provide children with healthy food options and improve their physical activity level, thus reducing the risk of obesity. ${ }^{12}$

Furthermore, obese children today are getting affected by diseases and health problems previously observed only in adults; many obese children today are developing health problems that once afflicted only adults. Chronic illnesses like diabetes mellitus and heart disease have an earlier onset and a prolonged course in these obese children, and even though the disease might remain undiagnosed until adulthood, the resulting complications are more severe leading to a shorter life. ${ }^{13}$ Childhood obesity leads to many short- and long-term complications (Table 1).

\section{Prevention of childhood obesity}

Prevention is the key to success for obesity control as many, but not all, obese children will eventually become obese adults. "Tracking" or the likelihood of persistence of childhood obesity into adulthood is related to the age. The management of obesity in adults is a difficult and often unsuccessful feat especially in the absence of a known organic etiopathogenesis (eg, leptin deficiency, other hormonal abnormalities). Prevention of childhood obesity on the other hand can be more rewarding, providing better chances for
Table I Complications associated with childhood obesity

\begin{tabular}{|c|c|}
\hline Acute ${ }^{14-16}$ & $\begin{array}{l}\text { - Type } 2 \text { diabetes } \\
\text { - Hypertension } \\
\text { - Hyperlipidemia } \\
\text { - Precocious puberty } \\
\text { - Ovarian hyperandrogenism } \\
\text { - Gynecomastia } \\
\text { - Cholecystitis } \\
\text { - Pancreatitis } \\
\text { - Pseudotumor cerebri } \\
\text { - Fatty liver } \\
\text { - Renal disease (focal glomerulosclerosis) }\end{array}$ \\
\hline Orthopedic disorders ${ }^{17}$ & $\begin{array}{l}\text { - Slipped capital femoral epiphysis } \\
\text { - Tibia vara } \\
\text { - Blount disease }\end{array}$ \\
\hline $\begin{array}{l}\text { Liver and gall bladder } \\
\text { dysfunction }{ }^{18}\end{array}$ & $\begin{array}{l}\text { - Elevated transaminases } \\
\text { - Cholecystitis }\end{array}$ \\
\hline $\begin{array}{l}\text { Physical and } \\
\text { psychological }{ }^{|9-2|}\end{array}$ & $\begin{array}{l}\text { - Depression } \\
\text { - Eating disorders } \\
\text { - Social isolation } \\
\text { - Sleep disorders }\end{array}$ \\
\hline $\begin{array}{l}\text { Cardiovascular and } \\
\text { endocrine }{ }^{22-24}\end{array}$ & $\begin{array}{l}\text { - Hyperinsulinism and insulin resistance } \\
\text { - Hypercholesterolemia } \\
\text { - Hypertriglyceridemia } \\
\text { - Low levels of high-density lipoprotein } \\
\text { - Hypertension } \\
\text { - Polycystic ovary syndrome } \\
\text { - Coronary artery disease } \\
\text { - Left ventricular hypertrophy }\end{array}$ \\
\hline Cancer ${ }^{17}$ & - Colorectal carcinoma \\
\hline Long-term ${ }^{23,25}$ & $\begin{array}{l}\text { - Ischemic heart disease } \\
\text { - Short life span } \\
\text { - Stroke } \\
\text { - Sudden death }\end{array}$ \\
\hline
\end{tabular}

reducing long-term complications. There are three levels of prevention in dealing with childhood obesity: ${ }^{26-28}$

1. Primordial prevention: deals with keeping a healthy weight and a normal BMI throughout childhood and into the teens.

2. Primary prevention: aims to prevent overweight children from becoming obese.

3. Secondary prevention: directed toward the treatment of obesity so as to reduce the comorbidities and reverse overweight and obesity if possible.

Inculcating healthy practices like plant-based foods and fruit consumption and inclusion of exercises and active lifestyle form the pillars of the prevention programme..$^{29-31}$

All the previously mentioned strategies when combined together can be put into practice sequentially from perinatal period to adolescence as follows:

- Perinatal: this includes adequate prenatal nutrition with optimal maternal weight gain, good blood sugar control 
in diabetics, postpartum weight loss with exercises and nutritional counseling. ${ }^{32}$

- Infancy: early initiation of breastfeeding, exclusive breastfeeding for 6 months followed by inclusion of solid foods, providing a balanced diet with avoidance of unhealthy calorie-rich snacks and close monitoring of weight gain. ${ }^{33-35}$

- Preschool: providing nutritional education to parents and children so as to develop healthy eating practices, offer healthy food preferences by giving early experience of different food and flavors, and following closely the rate of weight gain to prevent early adiposity rebound. ${ }^{36}$

- Childhood: monitoring both the weight and height, preventing excessive prepubertal adiposity, provide nutritional counseling, and emphasis on daily physical activity. ${ }^{37}$

- Adolescence: prevent the increase in weight after growth spurt, maintain healthy eating behavior, and reinforcing the need for daily exercises and workouts. ${ }^{38-39}$

Furthermore, advocate nutritional goals, such as the traffic light diet:

- Green-GO: includes food which are low in calories and can be eaten without any restrictions.

- Yellow - CAUTION: food items with moderate high calorie content and can be eaten only in moderation.

- Red - STOP: high calorie food items which should be avoided or eaten rarely. ${ }^{40,41}$

\section{Physical activity and behavior therapy}

Physical activity is the key component for prevention and management of obesity. ${ }^{42,43}$ Preschool children require unstructured activities and thus will benefit from outdoor play and games. On the other hand, school going children and adolescents require at least 60 minutes of daily physical activity out of which 30 minutes should be structured activities like sports and supervised exercises. ${ }^{44} 46$ This has also been recommended by American Academy of Pediatrics. ${ }^{47}$ Simply providing education on obesity-related health risks, nutrition, and physical activity is insufficient to induce behavioral change. The best-established counseling techniques used for pediatric obesity treatment use a behavioral change model, which includes the following elements:

- Self-monitoring of target behaviors (logs of food, activity, or other behaviors recorded by patient or family).

This allows the child and family to recognize the behaviors contributing to their weight gain. Clinician feedback throughout the self-monitoring process is essential to monitor the behavior change. A patient's food log may also identify other contributors to eating behaviors, such as the meal-time environment, boredom, and level of hunger, all of which can be valuable in the evaluation of stimulus control.

- Stimulus control to reduce environmental cues that contribute to unhealthy behaviors.

This includes reducing access to unhealthy behaviors (eg, removing some categories of food from the house or removing a television from the bedroom) and also efforts to establish new, healthier daily routines (such as making fruits and vegetables more accessible).

- Goal-setting for healthy behaviors rather than strict weight goals.

Goal-setting is widely used for inspiring behavioral change. However, the process can be detrimental if goals are not realistic and maintainable. Appropriate goals are Specific, Measurable, Attainable, Realistic, and Timely ("SMART").

- Contracting for selected nutrition or activity goals.

Contracting is the explicit agreement to give a reward for the achievement of a specific goal. This helps children focus on specific behaviors and provides structure and incentive to their goal-setting process.

- Positive reinforcement of target behaviors.

Positive reinforcement can be in the form of praise for healthy behaviors or in the form of rewards for achieving specific goals. The reward should be negotiated by the parent and the child, ideally facilitated by the provider to ensure that the rewards are appropriate. Rewards should be small activities or privileges that the child can participate in frequently, rather than monetary incentives or toys; food should not be used as a reward. ${ }^{48-53}$

Despite some discrepancy in study outcomes of increasing physical activity as a means to lower BMI, increasing the physical activity level of the child and family is a key focus in obesity treatment. ${ }^{54-57}$ As with nutrition goals, strategies for increasing physical activity are individualized. Clinicians should take into account the developmental stage of the child, family schedule, and personal preferences for activity, while being mindful of sedentary activity. Clinicians can support the change process by consistently advising children and families to be physically active, suggesting options and encouraging goal-setting. In addition, community participation can be encouraged by forming partnerships with local fitness centers and schools. To increase physical activity in children, it is often helpful to consider a variety of options. Structured physical activity (organized sports or performance arts) may be team-based or individual and competitive or noncompetitive. Less structured activities include recreational sports with peers or family, self-directed physical training, 
and lifestyle activity. Although these categories overlap, they provide expanded and diverse options and increase the opportunities for physical activity for the child and family. For preschool-aged children, unstructured activity like outdoor play is simple and useful. ${ }^{58}$ Providers can boost the level of activity in this age group by "prescribing" playground time and providing a list of local resources (playgrounds or other opportunities for active play), in addition to discouraging sedentary time (television use). The provider can also encourage parents to consider physical activity levels when they make choices regarding day care and after-school programs.

Substantial evidence supports the importance of reducing sedentary activity as a means of preventing and treating obesity in children..$^{59,60-63}$ Reducing sedentary activity has the secondary benefit of reducing the calorie intake and thus may prove to be more effective than increasing structured physical activity. ${ }^{54}$ In developed countries, overindulgence in leisure activities and entertainments like television, computer and Internet, virtual gaming, and other media are the root cause of sedentary lifestyle. In fact, television viewing is the single best established environmental cause in the evolution of childhood obesity. Data on the role of other media in the development of obesity are lacking. It is recommended that television viewing and other "screen time" (other than homework) is restricted to less than 2 hours daily, and that children under age 2 years avoid television altogether. ${ }^{64}$ Because many children initially will view television substantially more than this target, the first step should be in decreasing their present amount. School-wide campaigns and messages, and behavioral interventions using reinforcement and reward strategies have been effective in reducing television use. ${ }^{60}$

Behavioral treatment strategies, detailed earlier, such as self-monitoring, can also be useful. Children and families should first monitor their present amount of media use and then set goals to reduce it. The following recommendations are made in keeping with the American Academy of Pediatrics policy statement. ${ }^{64}$

- No television set in child's bedroom

- No television viewing during meals

- Maximum time for television and media viewing of 2 hours or some strategy that approximates this limit

- No media viewing for children under 2 years of age

Substituting healthier behaviors and entertainment is helpful for accomplishment of these goals. For younger children, this is through the use of "active games" such as tag, hula hooping, and obstacle courses. Quiet, nonmedia activities such as reading aloud or playing board games are also acceptable substitutes, because they avoid television advertising and establish patterns of family interaction that may ultimately lead to active play. Taking activity breaks during television commercials both reduces exposure to advertising and establishes specific windows for activity; an average hour of television features $\sim 20$ minutes of commercials with half of them being food related. Strategies to reduce media use for older children are more variable and are best addressed through a combination of self-monitoring, establishment of family media limits, and negotiation to identify substitute activities. Because both media and homework are often accessed through the computer, it can be difficult for a parent to monitor a child's actual media use. For these and other reasons, engagement of the child in the behaviorchange process is essential, using the behavioral strategies outlined earlier.

\section{Pediatric experience with drugs}

Experience with pediatric use of weight loss drugs has surfaced and some of the findings are promising. However, anorectic drugs are not recommended for routine use for childhood obesity. The efficacy and safety of these drugs have to be established by controlled clinical trials before prescribing them in prepubertal children. In the case of postpubertal adolescents who have failed to respond to behavioral therapy and diet modifications, use of anorectic drugs can be considered. All adolescents on medical therapy should be encouraged to engage in physical activity and should concurrently receive nutritional education and joint family counseling. ${ }^{65-70}$

\section{Newer modalities}

Many therapies that have been tried and are still in early phase or have met little success are "hunger training", which aims to teach people to eat only when blood glucose is below a set target. Although it appears promising as a weight loss strategy, it is still to be proved so. ${ }^{71}$ Based on the same principle, Biofeedback Enhanced Lifestyle Intervention has also been put to test in the recent past. ${ }^{72}$ For this technique (also known as "hunger recognition"), participants are given a portable self-monitoring (blood glucose) device and instructed to eat only when physical hunger is confirmed (blood glucose in the target range of 60-85 mg/dL). Many people find these techniques as uncomfortable, embarrassing, and inconvenient. In addition to the previously mentioned techniques, there are certain biochemical markers that are markers of satiety like glucagon-like peptide and cholecystokinin. Leptin is another useful marker primarily stimulated by carbohydrates in diet that can be used for long-term appetite responses. ${ }^{73}$ 
A lot needs to be investigated further to come to a complete understanding of this field.

\section{Conclusion}

Childhood obesity today constitutes one of the most serious health concerns, both in the developed and developing world. Obesity in childhood is causative for many chronic diseases, including type 2 diabetes, cardiovascular disease, hypertension, osteoporosis, and some carcinomas. It also has psychosocial consequences and may contribute to a delay in academic and social functioning as well as poor self-esteem and depression. The interventions for preventing and controlling obesity are mainly aimed at limiting the intake of sugar and high calorie snacks with higher consumption of vegetable- and fruit-based diet. This includes eating calcium-rich high-fiber diet with balanced micronutrients, daily healthy breakfasts and home cooked family meals, smaller portion size, and a curtailment in eating-out. Last but not least, decreasing the duration of "screen time", especially television, and increasing the level of physical activity are vital for preventing childhood obesity. Over the last 30 years, the prevalence of childhood obesity has increased exponentially. Multifaceted strategies involving the public and private health sectors along with community participation are required to gradually reverse this trend.

\section{Acknowledgment}

No external funding was secured for this study.

\section{Author contributions}

All authors made substantial contributions to conception and design, acquisition of data, or analysis and interpretation of data; took part in either drafting the article or revising it critically for important intellectual content; gave final approval of the version to be published; and agree to be accountable for all aspects of the work.

\section{Disclosure}

The authors have no financial relationships relevant to this article to disclose. The authors report no conflicts of interest in this work.

\section{References}

1. Plachta-Danielzik S, Kehden B, Landsberg B, et al. Attributable risks for childhood overweight: evidence for limited effectiveness of prevention. Pediatrics. 2012;130:e865.

2. Cole TJ, Bellizzi MC, Flegal KM, Dietz WH. Establishing a standard definition for child overweight and obesity worldwide: international survey. BMJ. 2000;320:1240-1243.
3. Caprio S, Daniels SR, Drewnowski A, et al. Influence of race, ethnicity, and culture on childhood obesity: implications for prevention and treatment: a consensus statement of Shaping America's Health and the Obesity Society. Diabetes Care. 2008;31:2211-2221.

4. Choudhary AK, Donnelly LF, Racadio JM, Strife JL. Diseases associated with childhood obesity. AJR Am J Roentgenol. 2007;188: $1118-1130$

5. Daniels SR, Arnett DK, Eckel RH, et al. Overweight in children and adolescents: pathophysiology, consequences, prevention, and treatment. Circulation. 2005;111:1999-2012.

6. Himes JH, Dietz WH. Guidelines for overweight in adolescent preventive services: recommendations from an expert committee. The Expert Committee on Clinical Guidelines for Overweight in Adolescent Preventive Services. Am J Clin Nutr. 1994;59:307-316.

7. Himes JH. Challenges of accurately measuring and using BMI and other indicators of obesity in children. Pediatrics. 2009;124(Suppl 1): S3-S22.

8. Freedman DS, Ogden CL, Berenson GS, Horlick M. Body mass index and body fatness in childhood. Curr Opin Clin Nutr Metab Care. $2005 ; 8(6): 618-623$

9. Malina RM, Katzmarzyk PT. Validity of the body mass index as an indicator of the risk and presence of overweight in adolescents. Am J Clin Nutr. 1999;70:131S-136S.

10. Harris KM, Gordon-Larsen P, Chantala K, Udry R. Longitudinal trends in race/ethnic disparities in leading health indicators from adolescence to young adulthood. Arch Pediatr Adolesc Med. 2006;160(1):74-81.

11. Schwimmer JB, Burwinkle TM, Varni JW. Health-related quality of life of severely obese children and adolescents. JAMA. 2003;289:1813-1819.

12. Must A, Jacques PF, Dallal GE, Bajema CJ, Dietz WH. Long-term morbidity and mortality of overweight adolescents. A follow-up of the Harvard growth study of 1922 to $1935 . N$ Engl J Med. 1992;327:1350-1355.

13. Dietz WH. Overweight in childhood and adolescence. $N$ Engl J Med. 2004;350:855-857.

14. Dietz WH. Health consequences of obesity in youth: childhood predictors of adult disease. Pediatrics. 1998;101:518-525.

15. Freedman DS, Khan LK, Dietz WH, Srinivasan SR, Berenson GS. Relationship of childhood obesity to coronary heart disease risk factors in adulthood: the Bogalusa Heart Study. Pediatrics. 2001;108:712-718.

16. Steinberger J, Moran A, Hong CP, Jacobs DR Jr, Sinaiko AR. Adiposity in childhood predicts obesity and insulin resistance in young adulthood. J Pediatr. 2001;138:469-473.

17. Morrison JA, Sprecher DL, Barton BA, Waclawiw MA, Daniels SR. Overweight, fat patterning, and cardiovascular disease risk factors in black and white girls: The National Heart, Lung, and Blood Institute Growth and Health Study. J Pediatr. 1999;135:458-464.

18. Hassink S. Problems in childhood obesity. Prim Care. 2003;30(2):357-374.

19. Vajro P, Fontanella A, Perna C, Orso G, Tedesco M, De Vincenzo A. Persistent hyperaminotransferasemia resolving after weight reduction in obese children. J Pediatr. 1994;125:239-241.

20. Amin R, Daniels SR. Relationship between obesity and sleepdisordered breathing in children: is it a closed loop? J Pediatr. 2002;140:641-643.

21. Willi SM, Oexmann MJ, Wright NM, Collop NA, Key LL Jr. The effects of a high-protein, low-fat, ketogenic diet on adolescents with morbid obesity: body composition, blood chemistries, and sleep abnormalities. Pediatrics. 1998;101:61-67.

22. Friedman MA, Brownell KD. Psychological correlates of obesity: mov ing to the next research generation. Psychol Bull. 1995;117:3-20.

23. Weiss R, Dziura J, Burgert TS, et al.. Obesity and the metabolic syndrome in children and adolescents. N Engl J Med. 2004;350:2362-2374.

24. Berenson GS, Srinivasan SR, Bao W, Newman WP III, Tracy RE, Wattigney WA. Association between multiple cardiovascular risk factors and atherosclerosis in children and young adults. The Bogalusa Heart Study. N Engl J Med. 1998;338:1650-1656. 
25. Pankow JS, Jacobs DR Jr, Steinberger J, Moran A, Sinaiko AR. Insulin resistance and cardiovascular disease risk factors in children of parents with the insulin resistance (metabolic) syndrome. Diabetes Care. 2004;27:775-780.

26. Guo SS, Roche AF, Chumlea WC, et al. The predictive value of childhood body mass index values for overweight at age 35 y. Am J Clin Nutr 1994;59:810.

27. Power C, Lake JK, Cole TJ. Body mass index and height from childhood to adulthood in the 1958 British born cohort. Am J Clin Nutr. 1997;66:1094.

28. Parsons TJ, Power C, Logan S, Summerbell CD. Childhood predictors of adult obesity: a systematic review. Int J Obes Relat Metab Disord. 1999;23(Suppl 8):S1.

29. Crinò A, Greggio NA, Beccaria L, Schiaffini R, Pietrobelli A, Maffeis C. Diagnosis and differential diagnosis of obesity in childhood. Minerva Pediatr. 2003;55:461-470.

30. Barlow SE, Trowbridge FL, Klish WJ, Dietz WH. Treatment of child and adolescent obesity: reports from pediatricians, pediatric nurse practitioners, and registered dietitians. Pediatrics. 2002;110:229-235.

31. Rhee K. Childhood overweight and the relationship between parent behaviors, parenting style, and family functioning. Ann Am Acad Pol Soc Sci. 2008;615:11-37.

32. Barlow SE. Expert committee recommendations on the assessment, prevention, and treatment of child and adolescent overweight and obesity: summary report. Pediatrics. 2007;120:S164-S192.

33. Contento IR, Basch C, Zybert P. Body image, weight, and food choices of Latina women and their young children. J Nutr Educ Behav. 2003;35:236-248.

34. Harder T, Bergmann R, Kallischnigg G, Plagemann A. Duration of breastfeeding and risk of overweight: a meta-analysis. Am J Epidemiol. 2005;162:397-403.

35. Gillman MW, Rifas-Shiman SL, Camargo CA Jr, et al. Risk of overweight among adolescents who were breastfed as infants. JAMA. 2001;285:2461-2467.

36. Hediger ML, Overpeck MD, Kuczmarski RJ, Ruan WJ. Association between infant breastfeeding and overweight in young children. JAMA. 2001;285:2453-2460.

37. MacArthur LH, Anguiano R, Gross KH. Are household factors putting immigrant Hispanic children at risk for becoming overweight: a community-based study in eastern North Carolina. J Community Health. 2004;29:387-404.

38. Powell LM, Szczypka G, Chaloupka FJ. Adolescent exposure to food advertising on television. Am J Prev Med. 2007;33(Suppl 4): S251-S256.

39. Pham KL, Harrison GG, Kagawa-Singer M. Perceptions of diet and physical activity among California Hmong adults and youths. Prev Chronic Dis. 2007;4(Suppl 4):A93.

40. McGovern L, Johnson JN, Paulo R, Hettinger A, Singhal V, Kamath C. Clinical review: treatment of pediatric obesity: a systematic review and meta-analysis of randomized trials. J Clin Endocrinol Metab. 2008;93:4600-4605.

41. Barlow SE, Dietz WH. Obesity evaluation and treatment: expert committee recommendations. Pediatrics. 1998;102:e29.

42. Yanovski JA. Intensive therapies for pediatric obesity. Pediatr Clin North Am. 2001;48:1041-1053.

43. Krebs NF, Jacobson MS. American Academy of Pediatrics Committee on Nutrition. Prevention of pediatric overweight and obesity. Pediatrics. 2003;112:424-430.

44. Epstein LH, Paluch RA, Beecher MD, Roemmich JN. Increasing healthy eating vs. reducing high energy-dense foods to treat pediatric obesity. Obesity (Silver Spring). 2008;16(2):318-326.

45. Atlantis E, Barnes EH, Singh MA. Efficacy of exercise for treating overweight in children and adolescents: a systematic review. Int J Obes (Lond). 2006;30:1027-1040.

46. Johnson LD, Delva J, O'Malley PM. Sports participation and physical education in American secondary schools: current levels and racial/ethnic and socioeconomic disparities. Am J Prev Med. 2007;33:S195-S208.
47. Crespo CJ, Smit E, Troiano RP, Bartlett SJ, Macera CA, Andersen RE. Television watching, energy intake, and obesity in US children: results from the third National Health and Nutrition Examination Survey, 1988-1994. Arch Pediatr Adolesc Med. 2001;155:360-365.

48. Epstein LH, Valoski A, Wing RR, McCurley J. Ten-year outcomes of behavioral family-based treatment for childhood obesity. Health Psychol. 1994;13:373.

49. Epstein LH, Myers MD, Raynor HA, Saelens BE. Treatment of pediatric obesity. Pediatrics. 1998;101:554.

50. Ross MM, Kolbash S, Cohen GM, Skelton JA. Multidisciplinary treatment of pediatric obesity: nutrition evaluation and management. Nutr Clin Pract. 2010;25:327.

51. De Santis-Moniaci D, Altshuler L. Comprehensive behavioral treatment of overweight and the pediatric practice. Pediatr Ann. 2007;36:102.

52. Robinson TN. Behavioural treatment of childhood and adolescent obesity. Int J Obes Relat Metab Disord. 1999;23(Suppl 2):S52.

53. Faith MS, Van Horn L, Appel LJ, et al. Evaluating parents and adult caregivers as "agents of change" for treating obese children: evidence for parent behavior change strategies and research gaps: a scientific statement from the American Heart Association. Circulation. 2012;125:1186.

54. Epstein LH, Roemmich JN, Paluch RA, Raynor HA. Influence of changes in sedentary behavior on energy and macronutrient intake in youth. Am J Clin Nutr. 2005;81:361.

55. Centers for Disease Control and Prevention (CDC). School health guidelines to promote healthy eating and physical activity. MMWR Recomm Rep. 2011;60:1.

56. Physical fitness and activity in schools. American Academy of Pediatrics. Pediatrics. 2000;105:1156.

57. United States Department of Agriculture, Center for Nutrition Policy and Promotion: Dietary guidelines for Americans, 2010. Available from: http://www.cnpp.usda.gov/dietaryguidelines.htm. Accessed on March 01, 2016.

58. Burdette HL, Whitaker RC, Daniels SR. Parental report of outdoor playtime as a measure of physical activity in preschool-aged children. Arch Pediatr Adolesc Med. 2004;158:353.

59. Oude Luttikhuis H, Baur L, Jansen H, et al. Interventions for treating obesity in children. Cochrane Database Syst Rev. 2009;1:CD001872.

60. Robinson TN. Reducing children's television viewing to prevent obesity: a randomized controlled trial. JAMA. 1999;282:1561.

61. Epstein LH, Valoski AM, Vara LS, et al. Effects of decreasing sedentary behavior and increasing activity on weight change in obese children. Health Psychol. 1995;14:109.

62. Waters E, de Silva-Sanigorski A, Hall BJ, et al. Interventions for preventing obesity in children. Cochrane Database Syst Rev. 2011;12:CD001871.

63. Guide to Community Preventive Services. Obesity prevention and control: behavioral interventions that aim to reduce recreational sedentary screen time among children. Available from: http://www.thecommunityguide.org/obesity/behavioral.html.

64. Strasburger VC, American Academy of Pediatrics. Council on Communications and Media. Policy statement--children, adolescents, substance abuse, and the media. Pediatrics. 2010;126:791.

65. Bacon GE, Lowrey GH. A clinical trial of fenfluramine in obese children. Curr Ther Res Clin Exp. 1967;9(12):626-630.

66. Malecka-Tendera E, Koehler B, Muchacka M, Wazowski R, Trzciakowska A. Efficacy and safety of dexfenfluramine treatment in obese adolescents. Pediatr Pol. 1996;71(5):431-436.

67. Centers for Disease Control and Prevention (CDC). Cardiac valvulopathy associated with exposure to fenfluramine or dexfenfluramine: U.S. Department of Health and Human Services interim public health recommendations, November 1997. MMWR Morb Mortal Wkly Rep. 1997;46(45):1061-1066.

68. Larsen TM, Toubro S, van Baak MA, et al. Effect of a 28-d treatment with L-796568, a novel beta(3)-adrenergic receptor agonist, on energy expenditure and body composition in obese men. Am J Clin Nutr. 2002; 76(4):780-788. 
69. Molnár D, Török K, Erhardt E, Jeges S. Safety and efficacy of treatment with an ephedrine/caffeine mixture. The first double-blind placebocontrolled pilot study in adolescents. Int J Obes Relat Metab Disord. 2000;24(12):1573-1578.

70. Garvey WT, Ryan DH, Look M, et al. Two-year sustained weight loss and metabolic benefits with controlled-release phentermine/ topiramate in obese and overweight adults (SEQUEL): a randomized, placebo-controlled, phase 3 extension study. Am J Clin Nutr. 2012;95(2):297-308.
71. Jospe MR, Brown RC, Roy M, Taylor RW. Adherence to hunger training using blood glucose monitoring: a feasibility study. Nutr Metab (Lond). 2015;12:22.

72. Ledoux T, Gallagher MR, Ciampolini M, Sampson M. Biofeedback enhanced lifestyle intervention: exploring the experience of participants in a novel intervention for disinhibited eating and obesity. Open J Prev Med. 2014; 4:779-788.

73. de Graaf C, Blom WA, Smeets PA, Stafleu A, Hendriks HF. Biomarkers of satiation and satiety. Am J Clin Nutr. 2004;79(6):946-961.

\section{Publish your work in this journal}

Diabetes, Metabolic Syndrome and Obesity: Targets and Therapy is an international, peer-reviewed open-access journal committed to the rapid publication of the latest laboratory and clinical findings in the fields of diabetes, metabolic syndrome and obesity research. Original research, review, case reports, hypothesis formation, expert opinion and commentaries are all considered for publication. The manuscript management system is completely online and includes a very quick and fair peer-review system, which is all easy to use. Visit http://www.dovepress.com/testimonials.php to read real quotes from published authors.

Submit your manuscript here: http://www.dovepress.com/diabetes-metabolic-syndrome-and-obesity-targets-and-therapy-journal 